\title{
Dynamics of the limnological features and diversity of zooplankton populations of the Cross River System SE Nigeria
}

\author{
B.O. Offem ${ }^{(1)}$, Y.A. Samsons ${ }^{(2)}$, I.T. Omoniyi( ${ }^{(2)}$, G.U. Ikpi ${ }^{(1)}$ \\ Received May 22, 2009 / Reçu le 22 mai 2009 \\ Revised August 7, 2009 / Révisé le 7 août 2009 \\ Accepted September 9, 2009 / Accepté le 9 septembre 2009
}

\section{ABSTRACT}

Key-words: $\quad$ Physico-chemical factors and zooplankton diversity were investigated spatial changes, seasonal changes, rainfall, water level, dissolved oxygen, transparency, temperature, zooplankton diversity over a two year period in three regions along the $200 \mathrm{~km}$ length of Cross River. The objective of the study was to quantify the relative importance of local environmental conditions and diversity of the principal zooplankton species within sampling sites. Mean conductivity, TDS and chlorides were highest upriver with values $289 \pm 198 \mu \mathrm{s} \cdot \mathrm{cm}^{-1}, 322.9 \pm 101 \mathrm{mg} \cdot \mathrm{L}^{-1}$, and $105.8 \pm 77.3 \mathrm{mg} \cdot \mathrm{L}^{-1}$ and lowest downriver with $123.5 \pm 78.9 \mathrm{mg} \cdot \mathrm{L}^{-1}$, $45.8 \pm 23.7 \mathrm{mg} \cdot \mathrm{L}^{-1}$ and $109 \pm 89 \mu \mathrm{s} \cdot \mathrm{cm}^{-1}$ respectively. Values of wet season water conductivity $\left(406 \pm 178 \mu \mathrm{s} \cdot \mathrm{cm}^{-1}\right)$, TDS $\left(420.4 \pm 267 \mathrm{mg} \cdot \mathrm{L}^{-1}\right)$, alkalinity $(289.9 \pm 34.7)$, total hardness $\left(205.8 \pm 37 \mathrm{mg} \cdot \mathrm{L}^{-1}\right)$, BOD $(1.7 \pm$ $0.2)$, chlorides $(205.8 \pm 37)$ and ammonium ions $\left(0.2 \pm 0.1 \mathrm{mg} \cdot \mathrm{L}^{-1}\right)$ were significantly higher than dry season values of $156 \pm 78.5 \mu \mathrm{s} \cdot \mathrm{cm}^{-1}, 0.2 \pm 0.1$, $123.8 \pm 15,101.4 \pm 87.9,0.2 \pm 0.1,78.1 \pm 34.8$ and $0.1 \pm 0.1 \mathrm{mg} \cdot \mathrm{L}^{-1}$ respectively. Out of twenty seven (27) zooplankton species identified Cladocerans (Ceriodaphnia, Evadne, Alona sp.) and Decapods (Lucifer, Penaeid nauphlius, and Hermit crab larva) were the most diverse taxonomic group, while Tintinnopsis was the only Ciliate. Rainfall value was positively correlated with hydrological characteristics (size of river, flow velocity, water level, and transparency), which in turn determined values of physicochemical properties and explained the observed seasonal and spatial changes in zooplankton diversity. Though water quality parameters were within the limits set by the World Health Organization (WHO) and European Economic Community (EEC) for good water, the changes in hydrological features of Cross River could be suspected to provide highly unstable aquatic habitat that could subsequently affect the stability of zooplankton and other aquatic organisms. 


\section{RÉSUMÉ}

Dynamique des paramètres limnologiques et diversité du zooplancton dans la rivière Cross (Niger)

\begin{abstract}
Mots-clés : variations spatiales, variations saisonnières, pluviométrie, niveau d'eau, oxygène dissous, transparence, température, zooplancton
\end{abstract}

Les paramètres physico-chimiques et la diversité du zooplancton ont été étudiés sur une période de deux ans le long de $200 \mathrm{~km}$ de la rivière Cross. L'objectif de cette étude était de quantifier l'importance relative des conditions environnementales locales et la diversité des principales espèces zooplanctoniques dans les sites échantillonnés. La conductivité moyenne, les TDS et les chlorures sont les plus élevés en amont avec les valeurs $289 \pm 198 \mu \mathrm{s} \cdot \mathrm{cm}^{-1}, 322,9 \pm 101 \mathrm{mg} \cdot \mathrm{L}^{-1}$, and 105,8 \pm $77,3 \mathrm{mg} \cdot \mathrm{L}^{-1}$ et plus basses en aval avec $123,5 \pm 78,9 \mathrm{mg} \cdot \mathrm{L}^{-1}, 45,8 \pm 23,7 \mathrm{mg} \cdot \mathrm{L}^{-1}$ et $109 \pm 89 \mu \mathrm{s} \cdot \mathrm{cm}^{-1}$ respectivement. En saison humide, la conductivité (406 \pm $\left.178 \mu \mathrm{s} \cdot \mathrm{cm}^{-1}\right)$, les TDS $\left(420.4 \pm 267 \mathrm{mg} \cdot \mathrm{L}^{-1}\right)$, l'alcalinité $(289,9 \pm 34,7)$, la dureté totale $\left(205,8 \pm 37 \mathrm{mg} \cdot \mathrm{L}^{-1}\right)$, la DBO $(1,7 \pm 0,2)$, les chlorures $(205,8 \pm 37)$ et les ions ammonium $\left(0,2 \pm 0,1 \mathrm{mg} \cdot \mathrm{L}^{-1}\right)$ sont significativement plus élevés qu'en saison sèche avec les valeurs de $156 \pm 78,5 \mu \mathrm{s} \cdot \mathrm{cm}^{-1} ; 0,2 \pm 0,1 ; 123,8 \pm 15 ; 101,4 \pm 87,9 ; 0,2 \pm$ 0,$1 ; 78,1 \pm 34,8$ and $0,1 \pm 0,1 \mathrm{mg} \cdot \mathrm{L}^{-1}$ respectivement. Parmi 27 espèces de zooplancton identifiées, les cladocères (Ceriodaphnia, Evadne, Alona sp.) et les décapodes (Lucifer, Penaeid nauphlius, and Hermit crab larva) sont les groupes les plus divers alors que Tintinnopsis est le seul cilié. Les valeurs de pluviométrie sont corrélées avec les caractéristiques hydrologiques (dimension de la rivière, vitesse du courant, niveau d'eau et transparence) qui en conséquence déterminent les valeurs physico-chimiques et expliquent les changements saisonniers et spatiaux dans la diversité du zooplancton. Bien que les paramètres de qualité soient dans les limites définies par l'Organisation Mondiale de la Santé (OMS) et la Communauté Économique Européenne (CEE) pour l'eau de bonne qualité, les changements dans les paramètres hydrologiques de la rivière Cross laissent suspecter que l'habitat aquatique est très instable et qu'il pourrait en conséquence affecter la stabilité du zooplancton et d'autres organismes aquatiques.

\section{INTRODUCTION}

Water is essential for the development and maintenance of the dynamics of every facet of the society (UNSCD, 2000). Availability of safe and reliable source of water is an essential pre-requisite for sustained development. Pollution in most Nigerian inland wetlands has been attributed to environmental degradation due to anthropogenic inputs from agriculture, irrigation, urbanization, mining, fire and industrialization of neighboring communities (Viner, 1970; King, 1988; Jamu and Ayinla, 2003). Among the very toxic elements are heavy metals. The heavy metals of interest include lead ( $\mathrm{Pb}$ ), chromium ( $\mathrm{Cr}$ ), cadmium (Cd), iron (Fe), zinc $(\mathrm{Zn})$, copper $(\mathrm{Cu})$ and manganese $(\mathrm{Mn})$. These trace elements are usually present in the environment in minute quantities, but are potentially toxic to aquatic biota and humans.

Continuous urban development and large solid waste pose as major environmental risks because of their difficulties in disposal. Landfills and other solid waste disposal site are major targets of pollution because rainfall and ground water leach these highly contaminated substances into rivers which are used by coastal communities. Water borne diseases kill 50000 people daily (Herschy, 1999) and both terrestrial and aquatic life may be poisoned, distort water quality and hinder economic activities.

Water quality monitoring is therefore of immense importance to activities involving the use of water bodies in the management of fisheries, water supply, pollution, sewage reservoir and impoundment (Adebisi, 1981; Ayodele and Ajani, 1999). A comprehensive knowledge of the limnological features is imperative for assessing its productivity (Adebisi, 1981). It involves the assessment of physico-chemical and hydrological parameters of water bodies, which is a function expressed as pollution parameters (Adeniji and Ovie, 1981, 1982). The effects of these inputs on water quality and aquatic life particularly in the Niger-Delta region have been 
investigated (Akpan and Offem, 1993a; Izonfuo and Bariweni, 2001; Olajire et al., 2003). Impacted changes in water quality as reflected in the biotic community structure, has been investigated (Boyd, 1981; Ezra and Nwankwo, 2001). Other studies on Nigerian aquatic ecosystem impairment have been reported (Imevbore, 1967; Smith and Powell, 1971; Azionu, 1983; APHA, 1987; Akpan and Offem, 1993a; Antia and Holzlohner, 1996). Recently, World Bank report noted that the problem associated with lack of quality freshwater in Nigeria threatens to place the health of about 40 million people at risk. The study suggests that it would cost in excess of US $\$ 9$ million a year to such problems if freshwater contamination is not checked (FEPA, 1989).

The stability of zooplankton in any aquatic body of water is of profound importance because they represent important and sometimes unique food source for fish and many aquatic vertebrates (Ochang et al., 2005). They are an important link in food chains of virtually every inland water body converting phytoplankton/benthic plants, bacteria, fungi and decaying organic matter into animal tissue that can be used by larger animal.

The Cross River, despite its strategic role as one of the sources of water supply for communities around it and its use for domestic activities, agriculture, fishing, livestock grazing, transport and fish farming, no research work has been carried out to ascertain the water quality of Cross River across spatial and temporal scale and the influence on aquatic biota. The objective of this study was to quantify the relative importance of local environmental conditions prevailing within sampling sites and the occurrence of the principal zooplankton species in the upper, middle and lower portions of the river.

\section{MATERIALS AND METHODS}

\section{> STUDY SITE AND SAMPLING PROCEDURE}

The study site is the Cross River, a floodplain river located at the south eastern part of Nigeria on latitude $4^{\circ} .25^{\prime}-7^{\circ} .00^{\prime} \mathrm{N}$, longitude $7^{\circ} .15^{\prime}-9^{\circ} .30^{\prime} \mathrm{E}$ (Figure 1). It is bounded in the south by the Atlantic Ocean, east by the Republic of Cameroun, the Nigerian states of Benue in the North, Ebonyi and Abia in the west and Akwa Ibom in the south-west. Climate of the study area is characterized by a dry season from November-March and wet season from April-October. Highest precipitation $(3050 \pm 230 \mathrm{~mm})$ occurs in August, and lowest $(300 \pm$ $23 \mathrm{~mm}$ ) in March. The mean annual temperature ranges from $15.5 \pm 7.6^{\circ} \mathrm{C}$ in wet period to $32.6 \pm 5.4^{\circ} \mathrm{C}$ in dry period.

As obtained in river-floodplain system Cross River comprised a wide range of habitat types, from small upland streams, smooth glides of the middle sections, and broad, meandering river stretch, of the lowland. Such longitudinal zonation is widely described in textbooks about river systems (Welcomme, 1985). The principle driving force for the productivity of major biota in Cross River floodplain systems is the seasonal variation of the river flows or "flood pulse", which produces periodic inundations of the floodplain. The bulk of the productivity is derived directly or indirectly within the floodplain itself.

In this study, three sampling sites were selected randomly, one each upriver, middle river and downriver. Upriver site is located $3 \mathrm{~km}$ from the river boundary with the Cameroun with rocky, gravel and sandy substratum. The shoreline is covered with savanna grassland, and wood and paper industries are located in the site. The middle river site is at $100 \mathrm{~km}$ distance from river boundary with Cameroun (in the Nigerian side); it has a rocky substratum and shoreline and is sparsely shaded by forest and savanna grassland. Downriver has a muddy substratum and opens into the Cross River estuary, with shoreline thickly shaded with rainforest.

\section{> HYDROLOGICAL PARAMETERS}

Monthly rainfall data for the study area were obtained from three meteorological stations, each located at the sampling sites. Water level was determined with a lead sinker attached 


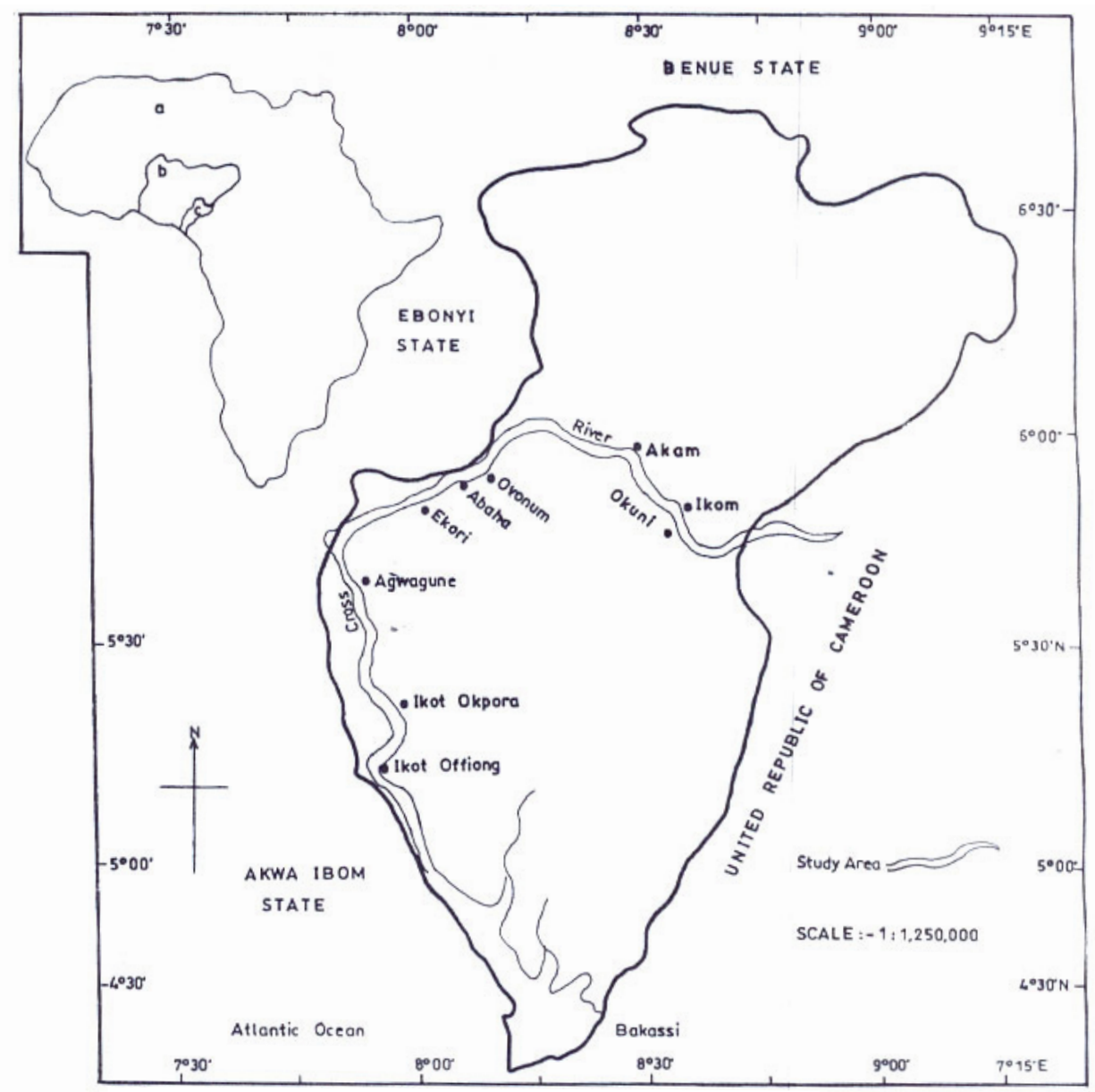

\section{Figure 1}

Map of Cross River showing study area. (Source: Ministry of Lands and survey, Cross River State, Nigeria.)

\section{Figure 1}

Carte de la rivière avec localisation des secteurs étudiés.

to a calibrated rope. The sinker was lowered down into water until it reached the substrate. The depth was then read from the calibrated rope. The procedure was repeated in two other locations randomly selected from the edge and middle of water within the sampling site. In smaller sites water level was determined by a rope marked at $2.5 \mathrm{~m}$ interval and strung across the river. A measuring pole was used at every marker to determine the depth at that point. For larger sites a Lowrance depth sounder was used to take a reading every five seconds while crossing the river at a steady speed. River width was measured with a long calibrated rope in three places in each sampling sites and the average was taken. The water flow velocity was determined with a water current meter (Wagtech current master model Wag-WE50420).

\section{> WATER QUALITY PARAMETERS}

Monthly measurements of physico-chemical parameters were taken in situ for 24 months (January 2005-January 2007) in all sampling stations during wet and dry seasons.

Temperature values were recorded from a mercury-in glass thermometer graduated in units of ${ }^{\circ} \mathrm{C}\left(50^{\circ} \mathrm{C}\right)$ by immersing the thermometer slightly under the surface of water $(2 \mathrm{~cm})$ for five minutes until mercury stood at one place. Pye Unicam Model 7065 electronic pH meter 
at $25{ }^{\circ} \mathrm{C}$ after standardization with buffer solution at $\mathrm{pH} 4,7$ and 9 was used for $\mathrm{pH}$. The dissolved oxygen concentration of the water samples was determined with a Fischers digital oxygen analyzer. Water transparency was measured by use of Secchi disc (Golterman, 1969). The transparency of the water at that station was the mean of the two readings. For the total dissolved solids (TDS), the Hach TDS meter was put on, the reading zeroed and then the electrode dipped into the water sample and the reading taken approximately. Conductivity was assessed by putting on the Suntex conductivity meter, adjusting the reading portion and dipping the meter into the water sample and approximate reading taken.

To assess the levels of the heavy metals, running water $(2.0 \mathrm{~L})$ from the three sites of the river were collected from plastic containers that have been evacuated and fully sterilized. A portion of the water sample $(50 \mathrm{~mL})$ were fixed using concentrated nitric acid and hydrochloric acid in a ratio of 1:10 respectively, which was meant to digest particulate matter inside the sample by heating in a water bath to obtain thick yellow solution, and later was cooled and made up to $100 \mathrm{~mL}$ with distilled water. The samples were then directly analyzed using the Bulk Scientific Atomic Absorption Spectrophotometer (AAS). For each heavy metal, specific concentration standard was run, to prepare a calibration curve from which the concentration of the heavy metal was read directly from the AAS VDU system.

The samples collected from each station were analyzed for alkalinity, hardness and chlorides using standard methods (Framan, 1981; APHA, 1987).

Zooplankton was collected by plankton standard net with $68 \mu \mathrm{m}$ mesh size and then preserved in Transeau's solution. The numerical assessment of zooplankton was done by Sedgewick-Rafter counting cell. They were identified with the help of a compound microscope using keys given by Ward and Whipple (1959), Mellanby (1963) and Needham and Needham (1972).

\section{> DATA TREATMENT AND ANALYSIS}

Mean and standard deviation of each of the physico-chemical parameters were calculated. Analysis of variance (ANOVA) was used to test for statistical differences between the means of the physical and chemical parameters of the sampling sites. Student's t-test was used to test for differences between seasons. To calculate zooplankton composition, numbers in different samples were summed for each species and averaged across all sampling sites. Physico-chemical parameters were correlated with the percentage composition of zooplankton species using Pearson product moment correlation coefficient analysis.

\section{RESULTS}

\section{> ENVIRONMENTAL PARAMETERS}

Table I showed that mean rainfall $(\mathrm{cm})$ values, water level $(\mathrm{m})$, water width $(\mathrm{m})$, current speed $\left(\mathrm{m} \cdot \mathrm{s}^{-1}\right)$, surface temperature $\left({ }^{\circ} \mathrm{C}\right)$, conductivity $\left(\mu \mathrm{s} \cdot \mathrm{cm}^{-1}\right)$, TDS $\left(\mathrm{mg} \cdot \mathrm{L}^{-1}\right)$, alkalinity $\left(\mathrm{mg} \cdot \mathrm{L}^{-1}\right)$, total hardness $\left(\mathrm{mg} \cdot \mathrm{L}^{-1}\right)$, chlorides $\left(\mathrm{mg} \cdot \mathrm{L}^{-1}\right)$, iron $(\mathrm{Fe}) \mathrm{mg} \cdot \mathrm{L}^{-1}$, zinc $(\mathrm{Zn}) \mathrm{mg} \cdot \mathrm{L}^{-1}$, manganese $(\mathrm{Mn}) \mathrm{mg} \cdot \mathrm{L}^{-1}$, vary significantly $(P<0.05)$ between sampling sites while water transparency $(\mathrm{cm})$, dissolved $\mathrm{O}_{2}\left(\mathrm{mg} \cdot \mathrm{L}^{-1}\right)$, $\mathrm{pH}$ values, $\mathrm{BOD}\left(\mathrm{mg} \cdot \mathrm{L}^{-1}\right)$, silicates $\left(\mathrm{SiO}_{2}\right) \mathrm{mg} \cdot \mathrm{L}^{-1}, \mathrm{NH}_{4}\left(\mathrm{mg} \cdot \mathrm{L}^{-1}\right)$, lead $(\mathrm{Pb})\left(\mathrm{mg} \cdot \mathrm{L}^{-1}\right)$, chronium $(\mathrm{Cr})\left(\mathrm{mg} \cdot \mathrm{L}^{-1}\right)$ and copper $(\mathrm{Cu})\left(\mathrm{mg} \cdot \mathrm{L}^{-1}\right)$ were not significantly different between sites $(P>0.05)$.

All environmental parameters, except $\mathrm{pH}$ value, cadmium $(\mathrm{Cd})\left(\mathrm{mg} \cdot \mathrm{L}^{-1}\right)$, and manganese (Mn) $\left(\mathrm{mg} \cdot \mathrm{L}^{-1}\right)$, showed significant seasonal variations $(P<0.05)$ (Table II). The data showed that rain fell in most months (May-January) during the period of study, and that water level was positively correlated with rainfall intensity (Figure 2). Due to variation in flood regime caused by dry and wet season, the water level and river width fluctuate. The values of Secchi disc transparency were inversely proportional to the water level while variation in the monthly temperature and water conductivity were significant $(P<0.05)$ (Figure 3$)$. Monthly variation 
Table I

Mean $\pm S D$ of the environmental parameters of three portions surveyed in Cross River.

Tableau I

Moyenne \pm SD des paramètres environnementaux des trois secteurs de la rivière Cross étudiés.

\begin{tabular}{|c|c|c|c|}
\hline Enviromental parameters & Upriver & Midriver & Downriver \\
\hline Rainfall (cm) & $102.8 \pm 74.1^{a}$ & $254.9 \pm 141.6^{b}$ & $264.3 \pm 51.1^{\mathrm{C}}$ \\
\hline Water level (m) & $8.9 \pm 1.98^{\mathrm{a}}$ & $16.5 \pm 4.21^{b}$ & $47.9 \pm 4.9^{\mathrm{C}}$ \\
\hline Water width (m) & $1050 \pm 234^{a}$ & $1623 \pm 345^{b}$ & $2035 \pm 654^{c}$ \\
\hline Current speed $\left(\mathrm{m} \cdot \mathrm{s}^{-1}\right)$ & $0.93 \pm 0.34^{a}$ & $0.55 \pm 0.21^{b}$ & $0.24 \pm 0.18^{c}$ \\
\hline Surface temperature $\left({ }^{\circ} \mathrm{C}\right)$ & $27.4 \pm 1.5^{\mathrm{a}}$ & $26.0 \pm 1.4^{b}$ & $24.1 \pm 1.4^{\mathrm{C}}$ \\
\hline Transparency (cm) & $42.1 \pm 22.9^{a}$ & $37.2 \pm 19.5^{\mathrm{a}}$ & $33.7 \pm 14.3^{a}$ \\
\hline Dissolved $\mathrm{O}_{2}\left(\mathrm{mg} \cdot \mathrm{L}^{-1}\right)$ & $6.6 \pm 0.8^{a}$ & $6.8 \pm 0.9^{a}$ & $7.7 \pm 0.8^{a}$ \\
\hline pH value & $6.6 \pm 0.9^{a}$ & $7.2 \pm 0.7^{a}$ & $7.2 \pm 0.7^{\mathrm{a}}$ \\
\hline Conductivity ( $\mu \mathrm{s} \cdot \mathrm{cm}^{-1}$ ) & $289 \pm 198^{\mathrm{a}}$ & $189 \pm 94^{b}$ & $109 \pm 89^{c}$ \\
\hline TDS (mg $\left.\cdot \mathrm{L}^{-1}\right)$ & $322.9 \pm 101^{\mathrm{a}}$ & $208.8 \pm 78.3^{b}$ & $123.5 \pm 78.9^{C}$ \\
\hline Alkalinity $\left(\mathrm{mg} \cdot \mathrm{L}^{-1}\right)$ & $123.8 \pm 15.9^{a}$ & $207.4 \pm 67.5^{b}$ & $322.8 \pm 123^{c}$ \\
\hline Total hardness $\left(\mathrm{mg} \cdot \mathrm{L}^{-1}\right)$ & $89.9 \pm 34.7^{a}$ & $101.4 \pm 87.9^{b}$ & $176.9 \pm 76.9^{c}$ \\
\hline BOD $\left(\mathrm{mg} \cdot \mathrm{L}^{-1}\right)$ & $1.7 \pm 0.2^{a}$ & $1.8 \pm 0.2^{a}$ & $1.3 \pm 0.5^{a}$ \\
\hline Chlorides $\left(\mathrm{mg} \cdot \mathrm{L}^{-1}\right)$ & $105.8 \pm 77.3^{\mathrm{a}}$ & $78.1 \pm 45.8^{b}$ & $45.8 \pm 23.7^{\mathrm{C}}$ \\
\hline Silicates $\left(\mathrm{SiO}_{2}\right)\left(\mathrm{mg} \cdot \mathrm{L}^{-1}\right)$ & $2.89 \pm 1.8^{\mathrm{a}}$ & $3.4 \pm 0.8^{\mathrm{a}}$ & $3.9 \pm 1.4^{\mathrm{a}}$ \\
\hline $\mathrm{NH}_{4}\left(\mathrm{mg} \cdot \mathrm{L}^{-1}\right)$ & $0.2 \pm 0.1^{a}$ & $0.1 \pm 0.1^{a}$ & $0.1 \pm 0.1^{a}$ \\
\hline Lead $(\mathrm{Pb})\left(\mathrm{mg} \cdot \mathrm{L}^{-1}\right)$ & $0.27 \pm 0.1^{\mathrm{a}}$ & $0.1 \pm 0.02^{a}$ & $0.1 \pm 0.06^{a}$ \\
\hline Chronium (Cr) $\left(\mathrm{mg} \cdot \mathrm{L}^{-1}\right)$ & $0.2 \pm 0.1^{\mathrm{a}}$ & $0.1 \pm 0.01^{a}$ & $0.1 \pm 0.02^{a}$ \\
\hline Cadmium (Cd) $\left(\mathrm{mg} \cdot \mathrm{L}^{-1}\right)$ & $0.06 \pm 0.01^{a}$ & $0.02 \pm 0.01^{a}$ & $0.01 \pm 0.01^{a}$ \\
\hline Iron (Fe) $\left(\mathrm{mg} \cdot \mathrm{L}^{-1}\right)$ & $0.5 \pm 0.1^{\mathrm{a}}$ & $0.08 \pm 0.2^{b}$ & $0.04 \pm 0.02^{c}$ \\
\hline Zinc $(\mathrm{Zn})\left(\mathrm{mg} \cdot \mathrm{L}^{-1}\right)$ & $3.9 \pm 1.2^{a}$ & $1.2 \pm 0.8^{b}$ & $0.6 \pm 0.2^{c}$ \\
\hline Copper (Cu) $\left(\mathrm{mg}^{\prime} \mathrm{L}^{-1}\right)$ & $0.08 \pm 0.01^{a}$ & $0.01 \pm 0.01^{a}$ & $0.01 \pm 0.01^{a}$ \\
\hline Manganese $(\mathrm{Mn})\left(\mathrm{mg} \cdot \mathrm{L}^{-1}\right)$ & $1.2 \pm 0.1^{a}$ & $0.8 \pm 0.2^{b}$ & $0.4 \pm 0.2^{c}$ \\
\hline
\end{tabular}

Within rows, values with different superscript are significantly different $(P<0.05)$.

in the dissolved oxygen, $\mathrm{pH}$ value and TDS were significant with highest values of dissolved oxygen and $\mathrm{pH}$ occurring between February and April while the values of TDS were highest in months of July to September (Figure 4). Alkalinity, total hardness and biochemical oxygen demand (BOD) recorded highest values in the months of September and October and lowest in April in all three portions of the river (Figure 5). Apart from chromium, silica and copper that recorded higher concentrations during dry months of February to April, all other metals were highest in the months of September and October and lowest in April (Figure 6).

The upriver substrate was usually fine sand, coarse sand, and gravel while sand and rocks formed mid-river substrate, the downriver substrate was made up of clay and rocks. The banks were lined up by boulders and rocks in all portions of the river. Eco-regions (vegetation type) vary from savanna grassland, upriver, to rainforest downriver separated by mixed savanna and forest, mid-river. 
Table II

Seasonal variation in the physico-chemical parameters and the $t$-values of the student's $t$-test in the Cross River.

Tableau II

Variations saisonnières des paramètres physico-chimiques et des valeurs $t$ du test de Student dans la rivière Cross.

\begin{tabular}{|c|c|c|c|c|}
\hline Parameters & Wet season & Dry season & t-value & t-test \\
\hline \multicolumn{5}{|l|}{ Physical } \\
\hline Temperature $\left({ }^{\circ} \mathrm{C}\right)$ & $24.2 \pm 5.4$ & $29.6 \pm 3.3$ & 2.78 & $P<0.05$ \\
\hline Transparrency (m) & $15.3 \pm 4.8$ & $73.0 \pm 8.4$ & 5.22 & $P<0.05$ \\
\hline Water level (m) & $58.8 \pm 12.1$ & $8.2 \pm 2.5$ & 6.14 & $P<0.05$ \\
\hline Water width (m) & $461.5 \pm 108.8$ & $128.8 \pm 9.2$ & 5.99 & $P<0.05$ \\
\hline Flow velocity $\left(\mathrm{m} \cdot \mathrm{s}^{-1}\right)$ & $0.5 \pm 0.2$ & $0.2 \pm 0.1$ & 2.87 & $P<0.05$ \\
\hline Conductivity $\left(\mu \mathrm{s} \cdot \mathrm{cm}^{-1}\right)$ & $406 \pm 178$ & $156 \pm 78.5$ & 5.32 & $P<0.05$ \\
\hline \multicolumn{5}{|l|}{ Chemical } \\
\hline Dissolved oxygen $\left(\mathrm{mg} \cdot \mathrm{L}^{-1}\right)$ & $5.5 \pm 2.1$ & $7.7 \pm 1.5$ & 2.66 & $P<0.05$ \\
\hline pH value & $6.9 \pm 1.8$ & $7.9 \pm 0.8$ & 0.78 & $P>0.05$ \\
\hline TDS $\left(\mathbf{m g} \cdot \mathrm{L}^{-1}\right)$ & $534 \pm 231$ & $201 \pm 145$ & 4.33 & $P<0.05$ \\
\hline Alkalinity $\left(\mathrm{mg} \cdot \mathrm{L}^{-1}\right)$ & $420.4 \pm 267$ & $123.8 \pm 15$ & 4.78 & $P<0.05$ \\
\hline Total hardness $\left(\mathrm{mg} \cdot \mathrm{L}^{-1}\right)$ & $289.9 \pm 34.7$ & $101.4 \pm 87.9$ & 3.84 & $P<0.05$ \\
\hline BOD $\left(\mathrm{mg} \cdot \mathrm{L}^{-1}\right)$ & $1.7 \pm 0.2$ & $0.2 \pm 0.1$ & 4.98 & $P<0.05$ \\
\hline Chlorides $\left(\mathrm{mg} \cdot \mathrm{L}^{-1}\right)$ & $205.8 \pm 37.3$ & $78.1 \pm 34.8$ & 3.51 & $P<0.05$ \\
\hline Silicates $\left(\mathrm{SiO}_{2}\right)\left(\mathrm{mg} \cdot \mathrm{L}^{-1}\right)$ & $1.89 \pm 1.8$ & $3.4 \pm 0.8$ & 2.88 & $P<0.05$ \\
\hline $\mathrm{NH}_{4}\left(\mathrm{mg} \cdot \mathrm{L}^{-1}\right)$ & $0.2 \pm 0.1$ & $0.1 \pm 0.1$ & 2.67 & $P<0.05$ \\
\hline Lead $(\mathrm{Pb})\left(\mathrm{mg} \cdot \mathrm{L}^{-1}\right)$ & $0.3 \pm 0.1$ & $0.1 \pm 0.1$ & 2.33 & $P<0.05$ \\
\hline Chronium (Cr) $\left(\mathrm{mg} \cdot \mathrm{L}^{-1}\right)$ & $0.15 \pm 0.1$ & $0.25 \pm 0.1$ & 0.14 & $P>0.05$ \\
\hline Cadmium (Cd) $\left(\mathrm{mg} \cdot \mathrm{L}^{-1}\right)$ & $0.06 \pm 0.1$ & $0.01 \pm 0.01$ & 0.23 & $P>0.05$ \\
\hline Iron $(\mathrm{Fe})\left(\mathrm{mg} \cdot \mathrm{L}^{-1}\right)$ & $0.5 \pm 0.2$ & $0.06 \pm 0.02$ & 1.23 & $P<0.5$ \\
\hline Zinc $(\mathrm{Zn})\left(\mathrm{mg} \cdot \mathrm{L}^{-1}\right)$ & $4.1 \pm 1.2$ & $1.2 \pm 0.7$ & 0.98 & $P<0.05$ \\
\hline Copper (Cu) $\left(\mathrm{mg} \cdot \mathrm{L}^{-1}\right)$ & $1.1 \pm 0.2$ & $0.01 \pm 0.01$ & 0.88 & $P<0.05$ \\
\hline Manganese $(\mathrm{Mn})\left(\mathrm{mg} \cdot \mathrm{L}^{-1}\right)$ & $1.1 \pm 0.1$ & $0.9 \pm 0.1$ & 0.44 & $P>0.05$ \\
\hline
\end{tabular}

\section{>ZOOPLANKTON}

Total of twenty-seven (27) species, were identified during the study. Twenty-three (23) species were represented downriver, sixteen (16) mid-river and only twelve (12) occurred upriver. The Cladocera and Decapoda were the most diverse taxonomic group with eight species each. Other important groups were the Copepoda and Rotifera with four species each. Tintinnopsis, was the only ciliate present in the river and it occurred downriver (Table III). Wet season samples were represented by higher $(P<0.05)$ number $(25)$ of species than the dry (13). 


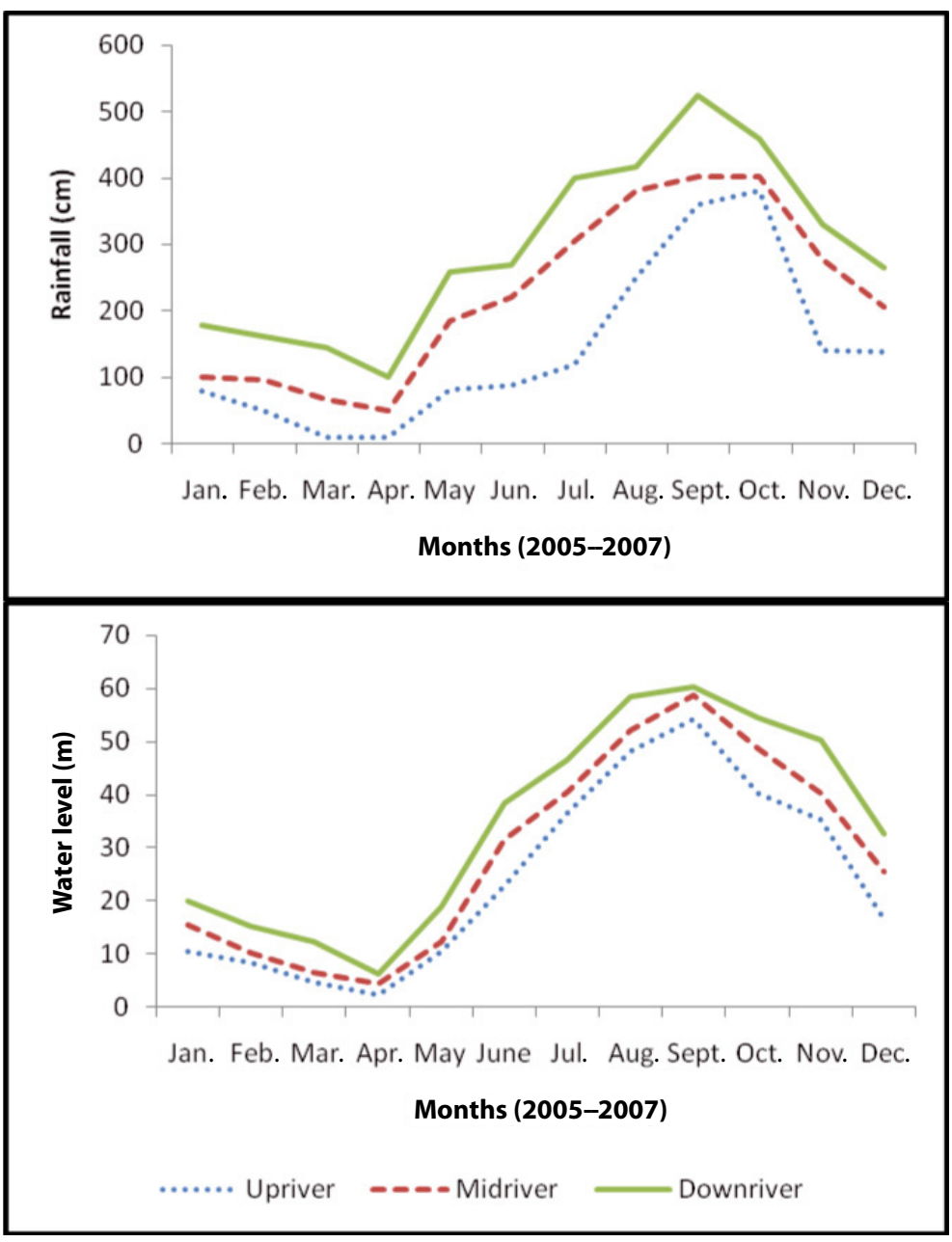

\section{Figure 2}

Monthly variations in the rainfall $(\mathrm{cm})$ and water level of Cross River wetlands.

\section{Figure 2}

Variations mensuelles des pluies $(\mathrm{cm})(\mathrm{A})$ et niveaux d'eau $(\mathrm{B})$ dans la rivière Cross.

The dry season decapod diversity was significantly higher (8) than the Cladocera (3) while the reverse was the case for the wet season samples (Table IV). Ciliates and Chaetognatha were absent during the dry season and rotifers were scarce being represented by only one species (Epiphanes). Only few species including: Alona sp. (Cladocera), Epiphanes (Rotifera), Chaeptoterus sp. and Ophiodromus (Polychaeta), Lucifer hansenii, Penaeid nauphlius, Mysid larvae, Hermit crab larva (Decapoda) showed year round presence.

Correlation coefficient between physico-chemical parameters and zooplankton diversity (Table V) showed that transparency, river width and temperature correlated positively $(P<0.001)$ with all the species caught apart from Polychaeta and Chaetognatha. The $\mathrm{pH}$ and dissolved oxygen values correlated with none. On the other hand all the copepods, cladocerans, ciliates, rotifers and decapods were all negatively correlated with water depth.

\section{DISCUSSION}

Physico-chemical parameters recorded in this study serve as indication of the level of water quality as a result of domestic, industrial and agricultural discharges into 


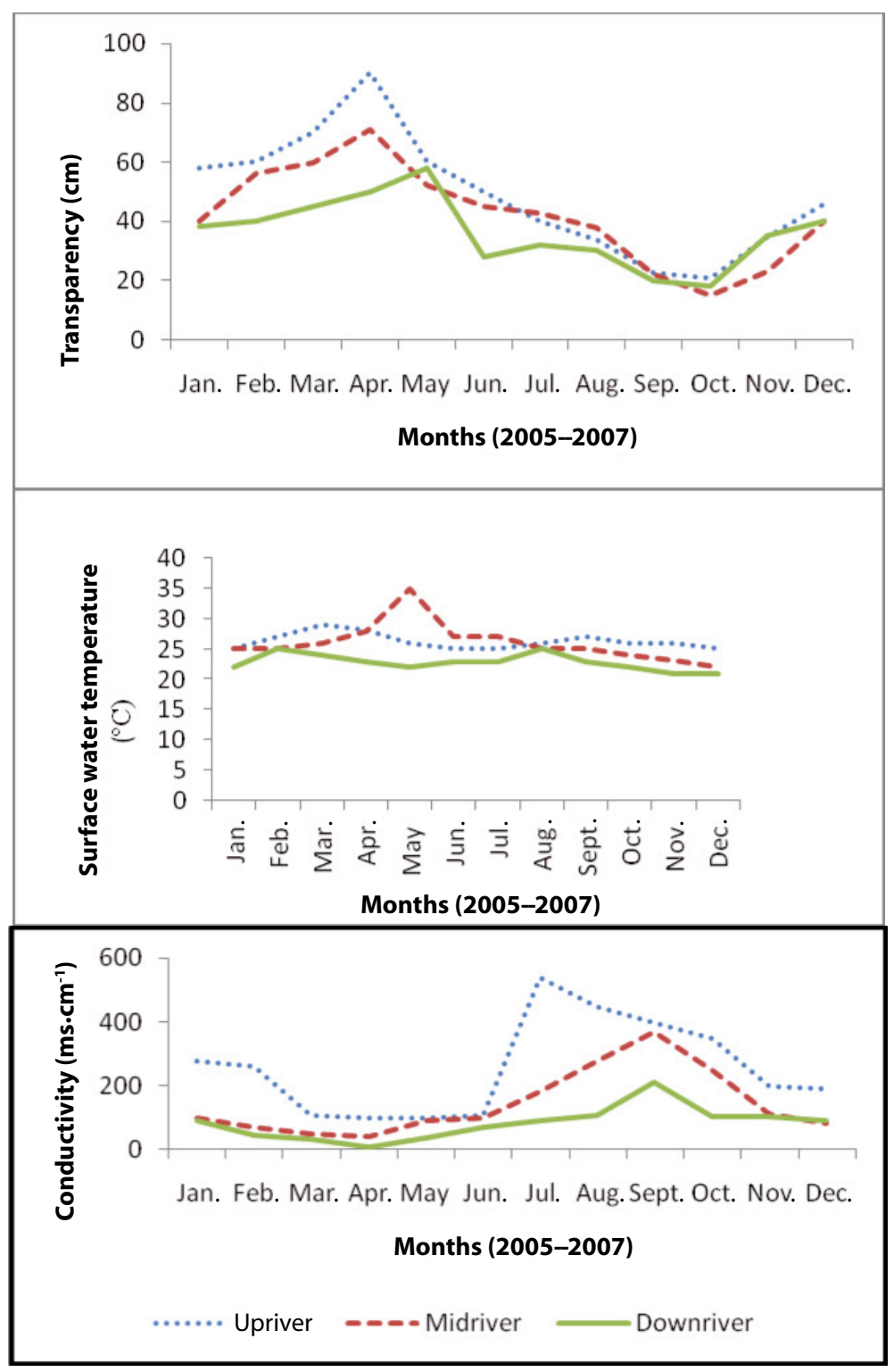

\section{Figure 3}

Monthly variations in the transparency $(\mathrm{cm})$, water temperature and water conductivity $\left(\mu \mathrm{s} \cdot \mathrm{cm}^{-1}\right)$ of Cross River wetlands.

\section{Figure 3}

Variations mensuelles de la transparence $(\mathrm{cm})$, la température de l'eau et la conductivité $\left(\mu \mathrm{s} \cdot \mathrm{cm}^{-1}\right)$ dans la rivière Cross.

Cross River wetlands. Positive correlation between water and rainfall indicate that the water level increases with increasing rainfall. Highest water level recorded upriver in October, mid-river in August and downriver in September showed that intensity of rainfall varied with the regions of water. Consistent high water level downriver throughout the study duration implied that rainfall was higher and of longer duration in this area. Variation in amount and duration of rainfall had been found (Egborge, 1994) to affect physico-chemical parameters of water which in turn affects growth of aquatic organisms and production (Adebisi, 1981). Inverse relationship between transparency and rainfall agrees with findings by Imevbore (1967) and Egborge (1977), in some of Nigerian inland waters. They explained that as flooding occurred due to heavy rainfall and consequent rise in water levels, run-off from nutrient rich 


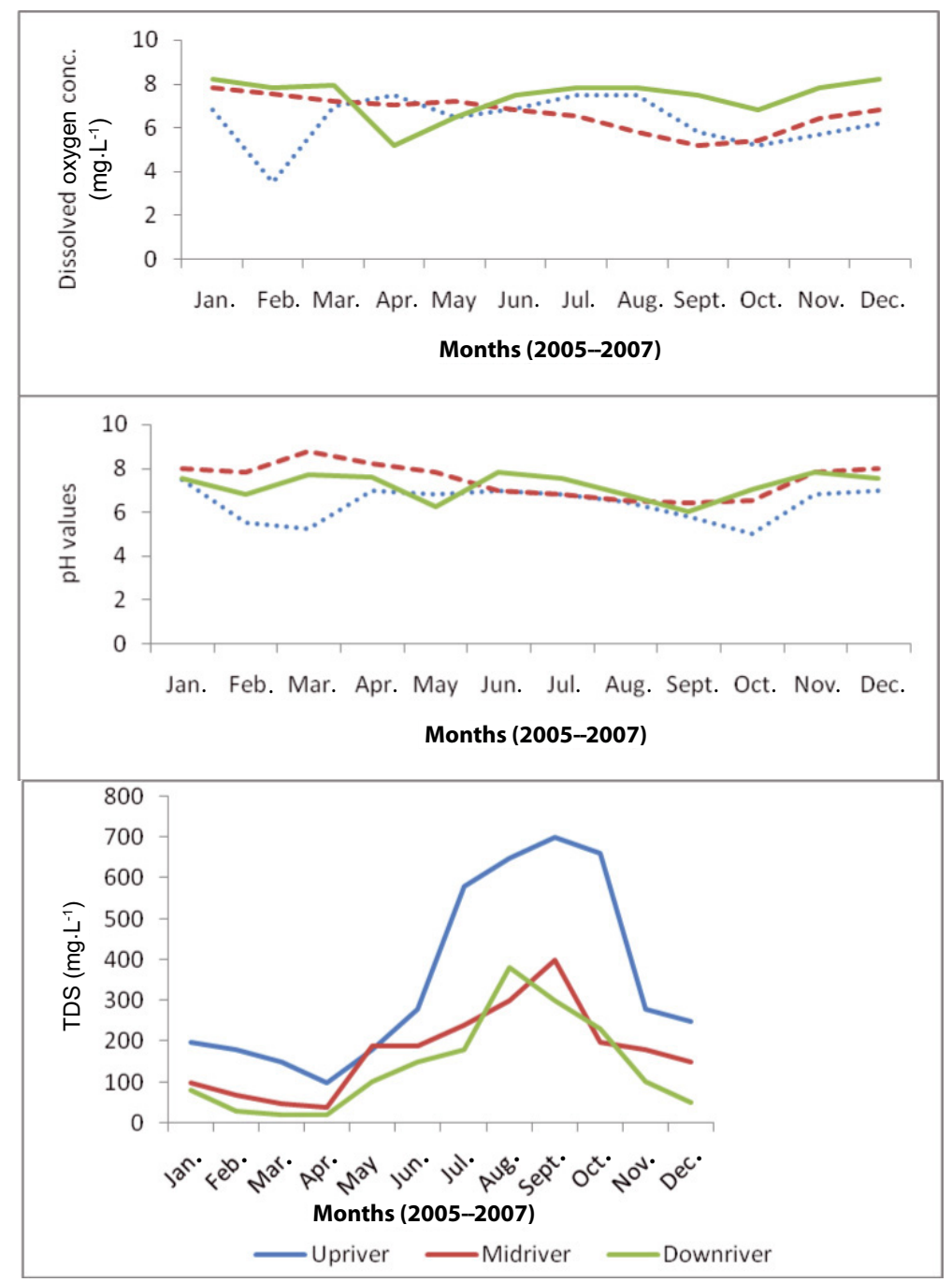

\section{Figure 4}

Monthly variation in the dissolved oxygen $\left(m g \cdot L^{-1}\right), p H$ value and TDS of the wetland of Cross River.

Figure 4

Variations mensuelles de l'oxygène dissous $\left(\mathrm{mg} \cdot \mathrm{L}^{-1}\right)$, du $\mathrm{pH}$ et TDS dans la rivière Cross.

agricultural lands increased, some particles and debris were carried along while others were re-suspended under action of wind. The resultant high rate of turbidity affects water transparency and consequent increase in the nutrient concentration.

The lower water temperatures recorded between December and February were due to cool dry North-East trade wind effect (harmattan) which was severe at this time of the year especially upriver. Low temperatures had earlier been recorded during this period by other workers in various Nigerian freshwater bodies (e.g. Hassan (1974), Boyd (1979), Adebisi (1981), Khan and Ejike (1984), Ovie and Adeniji (1993) and Ugwumba and Ugwumba (1993)). Low temperatures recorded in the three locations during the rains may be associated with thicker cloud cover, which Egborge (1994), in a similar study found to have a reducing effect on solar radiation and concentration of suspended particles which absorbs and scatter heat rays. High temperatures upriver could be due to the dry upland location with swift water movements and frequent dynamic changes in water flow. It may also be as a result of lower rainfall in the region. Low values in the temperature downriver, was attributed to higher rainfall in the area with calm water condition and slow flow rate occasioned by gentle terrain. 


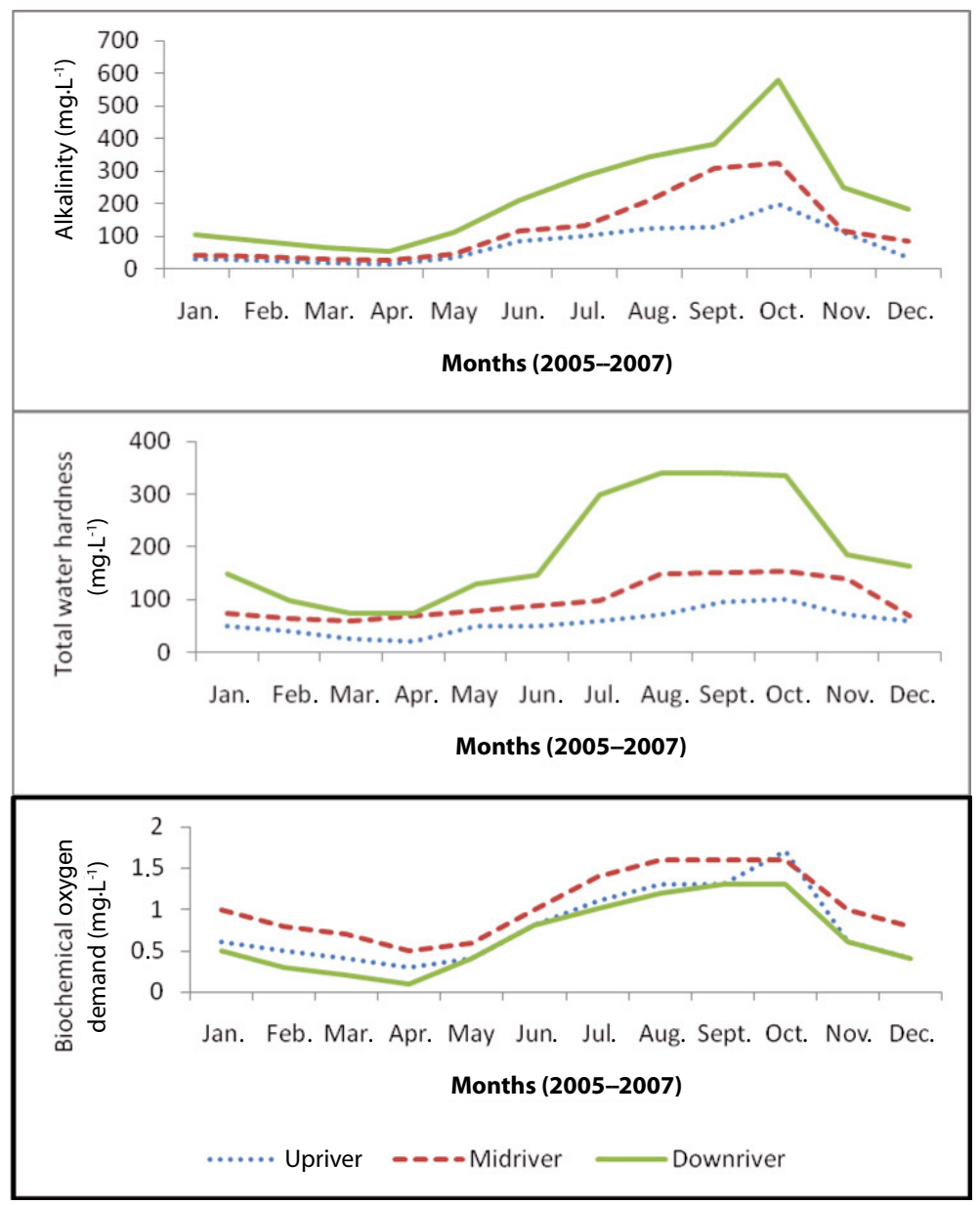

\section{Figure 5}

Monthly variation in the alkalinity, total hardness $\left(\mathrm{mg} \cdot \mathrm{L}^{-1}\right)$ and biochemical oxygen demand of the Cross River wetlands.

\section{Figure 5}

Variations mensuelles de l'alcalinité, la dureté totale $\left(\mathrm{mg} \cdot \mathrm{L}^{-1}\right)$ et de la demande biologique en oxygène (DBO) dans la rivière Cross.

Dissolved oxygen level recorded in this study is higher compared to $4.94-5.9 \mathrm{mg} \cdot \mathrm{L}^{-1}$ recorded for Ogun river (Adebisi, 1981) and 2.4-7.0 $\mathrm{mg} \cdot \mathrm{L}^{-1}$ for Calabar River (Asuquo et al., 1999) both in Nigeria. Low organic enrichment of a river had been suggested (Mason, 1992) as the possible reason responsible for such high oxygen values. The values of dissolved oxygen fell within the ranges (5.0-9.0 mg. $\mathrm{L}^{-1}$ ) documented by Swingle (1969), Boyd (1979) and Alabaster (1982) for good water quality suitable for aquatic organisms. Grossman and Freeman (1987) observed that high temperature produced high physiological demands and stress for aquatic organisms while reducing the oxygen saturation levels of water. Increased metabolic demands and decreased oxygen availability can prove limiting and lethal to aquatic organisms. Therefore, lower dissolved oxygen values obtained upriver could probably be due to higher temperatures in the region and the proximity to wood industry located in this area whose effluents coupled with submerged decaying woods can use up available dissolved oxygen. Seasonal variation observed in dissolved oxygen content with higher values during the rains could be due to lower water temperature and increased aeration. Egborge (1977) reported similar findings in Asere Lake in Nigeria. Higher dry season value of oxygen upriver and mid-river could be due to greater agitation rate by wind current in the dry season and higher photosynthetic activities. On the other hand, low dissolved oxygen observed during 


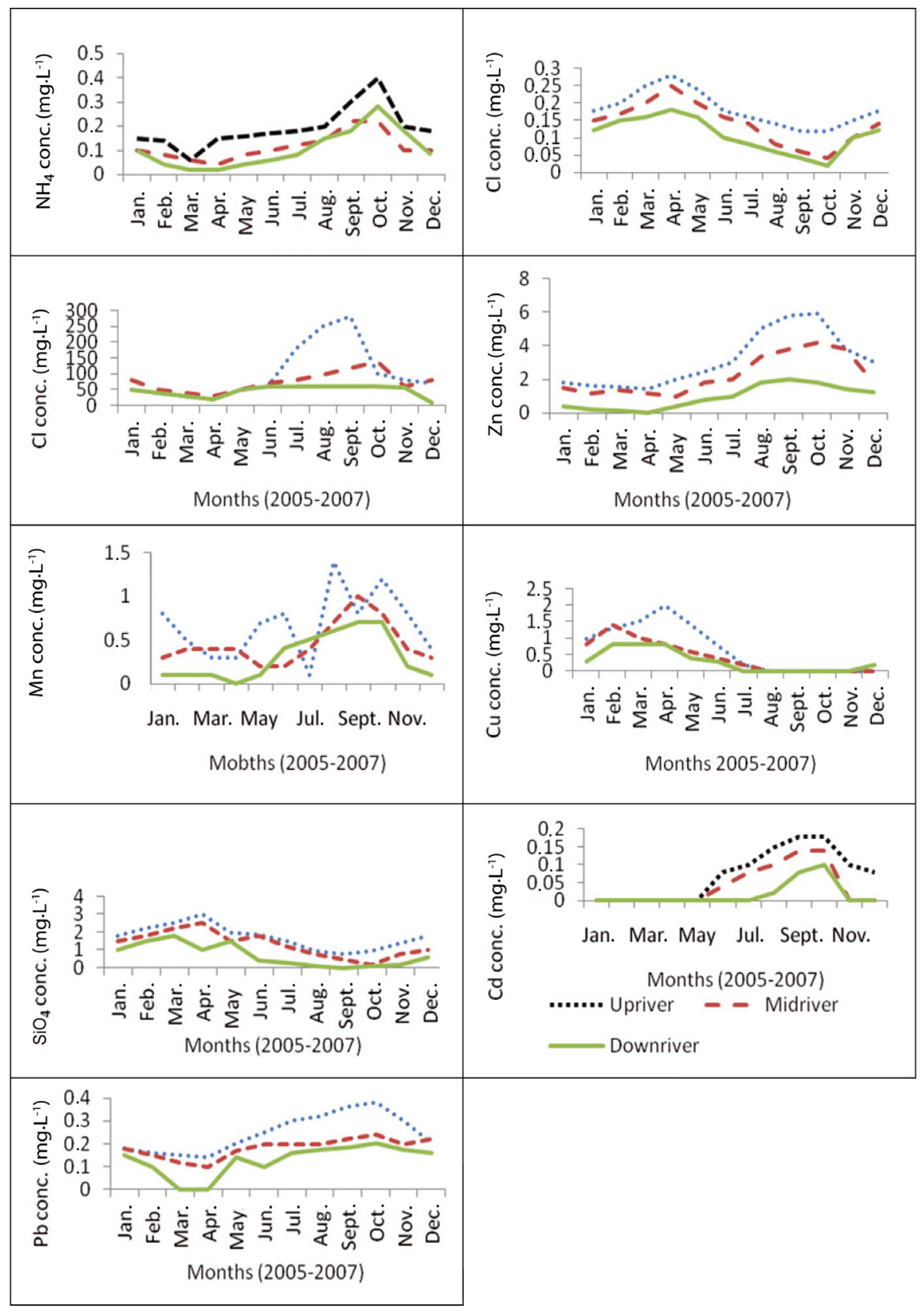

\section{Figure 6}

Monthly variation of $\mathrm{NH}_{4}^{+}, \mathrm{Cl}, \mathrm{Pb}, \mathrm{Cd}, \mathrm{Zn}, \mathrm{Si}, \mathrm{Mn}, \mathrm{Cu}$, and $\mathrm{Cr}$ in Cross River.

\section{Figure 6}

Variations mensuelles de $\mathrm{NH}_{4}^{+}, \mathrm{Cl}, \mathrm{Pb}, \mathrm{Cd}, \mathrm{Zn}, \mathrm{Si}, \mathrm{Mn}, \mathrm{Cu}$ and $\mathrm{Cr}$ dans la rivière Cross.

wet season could be attributed to oxidation of humic compounds available for decomposition as a result of inundation of lands, forest areas and wind velocity that seemed to be lower thus reducing the movement of the waters by wind action (Enrique, 1992). Also photosynthetic activity is reduced due to lower euphotic zone hence reduction in dissolved oxygen (Macan, 1974; Silva and Davies, 1987).

Average $\mathrm{pH}$ values obtained in this study agree with those documented by Swingle (1969) and Boyd (1981) as values most suitable for maximum productivity of aquatic organisms. 
Table III

Checklist of zooplankton species for the three river portions (January 2006 to December 2007).

Tableau III

Liste des espèces zooplanctoniques des trois secteurs de rivières (janvier 2006-décembre 2007).

\begin{tabular}{|c|c|c|c|}
\hline Family/species & Upriver & Midriver & Downriver \\
\hline \multicolumn{4}{|l|}{ Copepoda } \\
\hline Cyclops & - & + & + \\
\hline Mesocyclop notius & - & + & + \\
\hline Merocyclop & - & - & + \\
\hline Nauphlii & + & - & + \\
\hline \multicolumn{4}{|l|}{ Cladocera } \\
\hline Ceriodaphnia cornuta & + & + & + \\
\hline Daphnia magna & - & + & + \\
\hline Simocephalus & - & + & + \\
\hline Evadne tergestina & - & - & + \\
\hline Diaphanosoma sarsi & - & + & + \\
\hline Alona sp. & + & - & - \\
\hline Chydorus herrmani & - & - & + \\
\hline Ephemeroporus tridentatus & - & + & + \\
\hline \multicolumn{4}{|l|}{ Rotifera } \\
\hline Keratella tropica & + & - & - \\
\hline Epiphanes & + & - & - \\
\hline Branchionus falcatus & + & - & - \\
\hline Polyarthra & - & + & + \\
\hline \multicolumn{4}{|l|}{ Ciliata } \\
\hline Tintinnopsis & - & - & + \\
\hline \multicolumn{4}{|l|}{ Polychaete larva } \\
\hline Chaetopterus sp. & - & + & + \\
\hline Ophiodromus sp. & + & + & + \\
\hline \multicolumn{4}{|l|}{ Chaetognatha } \\
\hline Sagitta enflata & + & - & + \\
\hline Sagitta serratodentata & + & + & + \\
\hline \multicolumn{4}{|l|}{ Decapoda } \\
\hline Lucifer hansenii & + & + & - \\
\hline Bipinnaria larva & - & + & - \\
\hline Cerripede nauphlius & - & - & + \\
\hline Euphausid larva & - & + & + \\
\hline Penaeid nauphlius & - & + & + \\
\hline Mysid larvae & + & - & + \\
\hline Gastropod veliger & - & - & + \\
\hline Hermit crab larva & + & + & + \\
\hline
\end{tabular}


Table IV

Seasonal variation in the occurrence of zooplankton species in Cross River.

Tableau IV

Variations saisonnières de l'occurrence des espèces zooplanctoniques dans la rivière Cross.

\begin{tabular}{|c|c|c|}
\hline Family/species & Wet season & Dry season \\
\hline \multicolumn{3}{|l|}{ Copepoda } \\
\hline \multicolumn{3}{|l|}{ Cyclop } \\
\hline Mesocyclop notius & + & - \\
\hline Merocyclop & + & - \\
\hline Nauphlii & + & - \\
\hline \multicolumn{3}{|l|}{ Cladocera } \\
\hline Ceriodaphnia cornuta & + & - \\
\hline Daphnia magna & + & - \\
\hline Simocephalus & + & - \\
\hline Evadne tergestina & + & - \\
\hline Diaphanosoma sarsi & + & - \\
\hline Alona sp. & + & + \\
\hline Chydorus herrmani & - & + \\
\hline Ephemeroporus tridentatus & - & + \\
\hline \multicolumn{3}{|l|}{ Rotifera } \\
\hline Keratella tropica & - & + \\
\hline Epiphanes & + & + \\
\hline Branchionus falcatus & - & + \\
\hline Polyarthra & - & + \\
\hline \multicolumn{3}{|l|}{ Ciliata } \\
\hline Tintinnopsis & - & + \\
\hline \multicolumn{3}{|l|}{ Polychaete larva } \\
\hline Chaetopterus sp. & + & + \\
\hline Ophiodromus sp. & + & + \\
\hline \multicolumn{3}{|l|}{ Chaetognatha } \\
\hline Sagitta enflata & - & + \\
\hline Sagitta serratodentata & - & + \\
\hline \multicolumn{3}{|l|}{ Decapoda } \\
\hline Lucifer hansenii & + & + \\
\hline Bipinnaria larva & - & + \\
\hline Cerripede nauphlius & - & + \\
\hline Euphausid larva & - & + \\
\hline Penaeid nauphlius & + & + \\
\hline Mysid larvae & + & + \\
\hline Gastropod veliger & - & + \\
\hline Hermit crab larva & + & + \\
\hline
\end{tabular}




\section{Table $V$}

Pearson product moment correlation coefficient between physico-chemical parameters and invertebrate species in the Cross River.

$T=$ temperature, $\operatorname{Tr}=$ transparency, $D o=$ dissolved oxygen, $D t=$ river depth, $W d=$ river width, $V=$ flow velocity.

\section{Tableau V}

Coefficients de corrélation de Pearson entre les paramètres physico-chimiques et les espèces d'invertébrés dans la rivière Cross.

$\mathrm{T}=$ température, $\mathrm{Tr}=$ transparence, $\mathrm{Do}=$ oxygène dissous, $\mathrm{Dt}=$ profondeur de la rivière, $\mathrm{Wd}=$ largeur de la rivière, $V=$ vitesse du courant.

\begin{tabular}{|c|c|c|c|c|c|c|c|}
\hline Family/species & $\mathrm{T}\left({ }^{\circ} \mathrm{C}\right)$ & $\operatorname{Tr}(\mathrm{cm})$ & Do $\left(\mathrm{mg} \cdot \mathrm{L}^{-1}\right)$ & $\mathrm{pH}$ & Dt (m) & Wd $(m)$ & $V\left(m \cdot s^{-1}\right)$ \\
\hline \multicolumn{8}{|l|}{ Copepoda } \\
\hline Cyclop & 0.6332 & 0.5543 & 0.2255 & 0.0199 & -0.7611 & 0.6577 & 0.7766 \\
\hline Mesocyclop notius & 0.3421 & 0.6543 & 0.1998 & 0.1892 & -0.6565 & 0.5543 & 0.8778 \\
\hline Merocyclop sp. & 0.2234 & 0.5677 & 0.2541 & 0.0912 & -0.7651 & 0.6822 & 0.7886 \\
\hline Nauphlii & 0.3421 & 0.5676 & 0.3365 & 0.2149 & -0.6661 & 0.5644 & 0.7886 \\
\hline \multicolumn{8}{|l|}{ Cladocera } \\
\hline Ceriodaphnia cornuta & 0.2345 & 0.7688 & 0.2665 & 0.0129 & -0.5566 & 0.5765 & 0.7866 \\
\hline Daphnia magna & 0.2231 & 0.5876 & 0.2675 & 0.0693 & -0.6332 & 0.5566 & 0.8776 \\
\hline Simocephalus & 0.1254 & 0.5412 & 0.3422 & 0.2222 & -0.5443 & 0.6556 & 0.6674 \\
\hline Evadne tergestina & 0.231 & 0.6743 & 0.211 & 0.123 & -0.546 & 0.744 & 0.854 \\
\hline Diaphanosoma sarsi & 0.0987 & 0.5643 & 0.2221 & 0.0548 & -0.8769 & 0.5665 & -0.8776 \\
\hline Alona sp. & 0.2311 & 0.6534 & 0.433 & 0.334 . & -0.453 & 0.6544 & -0.6663 \\
\hline Chydorus herrmani & 0.2411 & 0.7985 & 0.2883 & 0.1928 & -0.7865 & 0.5764 & -0.5664 \\
\hline Ephemeroporus tridentatus & 0.3241 & 0.7642 & 0.4112 & 0.2323 & -0.5467 & 0.6332 & -0.8665 \\
\hline \multicolumn{8}{|l|}{ Rotifera } \\
\hline Keratella tropica & 0.3211 & 0.6577 & 0.1772 & 0.0598 & -0.2211 & 0.5111 & 0.4533 \\
\hline Epiphanes & 0.4356 & 0.5643 & 0.432 & 0.213 & -0.2365 & 0.666 & 0.546 \\
\hline Branchionu: & 0.6744 & 0.5665 & 0.3224 & 0.1111 & -0.5422 & 0.6222 & 0.5422 \\
\hline Polyarthra & 2432 & 0.5966 & 22 & 362 & -0.6225 & 0.5722 & 0.6554 \\
\hline \multicolumn{8}{|l|}{ Ciliata } \\
\hline Tintinnopsis & 0.6522 & 0.5066 & 0.2177 & 0.0449 & -0.8117 & 0.5663 & 0.4553 \\
\hline \multicolumn{8}{|l|}{ Polychaete larva } \\
\hline Chaetopterus sp. & 0.2131 & 0.5112 & 0.1998 & 0.2999 & 0.7666 & 0.6775 & -0.7665 \\
\hline Ophiodromus sp. & 0.1102 & 0.5003 & 0.0334 & 0.2991 & 0.6711 & 0.8557 & -0.5664 \\
\hline Chaetognatha & 0.0342 & 0.5562 & 0.0336 & 0.3223 & 0.5665 & 0.8455 & 0.3442 \\
\hline Sagitta enflata & 0.3244 & 0.6524 & 0.2209 & 0.0376 & -0.7866 & 0.3322 & 0.5443 \\
\hline Sagitta serratodentata & 0.4312 & 0.5211 & 0.3332 & 0.0333 & -0.4444 & -0.0544 & 0.6551 \\
\hline \multicolumn{8}{|l|}{ Decapoda } \\
\hline Lucifer hansenii & 0.1765 & 0.5044 & 0.1923 & 0.1928 & -0.7665 & -0.5666 & 0.9882 \\
\hline Bipinnaria larva & 0.2345 & 0.7532 & 0.332 & 0.234 & -0.453 & -0.632 & 0.865 \\
\hline Cerripede nauphlius & 0.2131 & 0.5522 & 0.0166 & 0.2981 & -0.6565 & 0.5664 & 0.7227 \\
\hline Euphausid larva & 0.7553 & 0.5122 & 0.3442 & 0.3091 & -0.8766 & -0.3332 & 0.5566 \\
\hline Penaeid nauphlius & 0.3321 & 0.5005 & 0.4222 & 0.1982 & -0.6555 & -0.6554 & 0.5566 \\
\hline Mysid larvae & 0.3233 & 0.6432 & 0.236 & 0.542 & -0.5642 & -0.7222 & 0.543 \\
\hline Gastropod veliger & 0.3421 & 0.5439 & 0.1922 & 0.0284 & 0.8777 & 0.5666 & 0.6437 \\
\hline Hermit crab larva & 0.4332 & 0.6543 & 0.564 & 0.5434 & 0.444 & 0.4443 & 0.8654 \\
\hline
\end{tabular}


High mean value recorded downriver could be due to combined effects of run-off from agricultural lands (with high concentration of lime) and photosynthetic activity of macrophytes. Rippey and Rippey (1986) made similar observation that there was increase in $\mathrm{pH}$ with photosynthesis. Low $\mathrm{pH}$ values in upper reach was attributed to anthropogenic acidification from the wood processing factory. Bayley (1981) observed that sawmill waste were toxic, when they cover the bottoms of water bodies, they decrease the $\mathrm{pH}$. Low wet season $\mathrm{pH}$ values might be due to higher input of allochthonous organic matter.

None of the samples used for determining TDS was up to maximum admissible concentration $\left(600 \mathrm{mg} \cdot \mathrm{L}^{-1}\right)$ of total solids as stipulated by WHO and EEC. The guide limit (EEC, 1976) of water conductivity is $400 \mu \mathrm{s} \cdot \mathrm{cm}^{-1}$. From our data, only the wet season samples $\left(406 \pm 178 \mu \mathrm{s} \cdot \mathrm{cm}^{-1}\right)$ exceeded this guide limit. Though normal biological activity is restricted to $\mathrm{pH}$ of $6-8$, for natural water, the EEC (1980) guide limit for water requiring simple physical treatment and disinfection is 6.5-8.5. Our water samples from the three sampling sections of the river and the two seasons in the study area, recorded $\mathrm{pH}$ values within 6.5-8.5.

The higher levels upriver of all heavy metals investigated might be due to location of industries in this section of the river. Higher level concentration of heavy metals in wet season samples may be due to effluents through runoff and water-sediment mixing process which is at maximum due to wind and storm during this season (Somers and Harvey, 1984). We have reasons to be very concerned because although WHO (1998) recommended $0.1 \mathrm{mg} \cdot \mathrm{L}^{-1}$ for $\mathrm{Pb}$ and $0.003 \mathrm{mg} \cdot \mathrm{L}^{-1}$ for $\mathrm{Cd}$, all upriver and wet season samples where these metals were detected exceeded the limit and therefore were potentially toxic. Results have showed that concentrations of lead $(\mathrm{Pb})$ in excess of $0.19 \mathrm{mg} \cdot \mathrm{L}^{-1}$ and $0.30 \mathrm{mg} \cdot \mathrm{L}^{-1}$ can be potentially harmful to Daphnia magna and Cyclop spp. respectively (Offem et al., 2008).

Cadmium has long biological life of about 20-30 years. Chronic exposures may eventually accumulate to levels toxic even to man (Hodgson and Levi, 1987). The WHO (1998) recommended limit for $\mathrm{Cr}$ is $0.05 \mathrm{mg} \cdot \mathrm{L}^{-1}$ but our dry season and upriver samples far exceeded the limit. Though an essential trace nutrients and a vital component for the glucose tolerance factor, chromium toxicity damages the liver and kidney (WHO, 1988; O'Flaherty, 1995). For $\mathrm{Cu}$, the recommended level in water is $20 \mathrm{mg} \cdot \mathrm{L}^{-1}$ (Pearson, 1976) and values of $\mathrm{Cu}$ detected in this study were far below the recommended limit. Iron is an essential metal but due to frequent acute and chronic Fe overload may results in renal failure (Muller-Eberhard et al., 1977). There were very unacceptable levels of Fe upriver and in wet season samples which may constitute risk to health. Considering the WHO standard of $0.01 \mathrm{mg} \cdot \mathrm{L}^{-1}$, some of the samples were overloaded. Zinc is an essential trace metal and all the samples contain appreciable concentrations. WHO action level for Zinc is $3 \mathrm{mg} \cdot \mathrm{L}^{-1}$ which is below the concentrations of wet season samples in this study. However, Zn does not accumulate with continuous exposure and body content is modulated by homeostatic mechanism that acts mainly on liver levels (Walshe et al., 1995). Manganese is an essential element and co-factor for several enzymatic reactions. WHO (1984) action level for Manganese is $0.1 \mathrm{mg} \cdot \mathrm{L}^{-1}$. Therefore, results from all samples showed major threats from Mn poisoning. Mena et al. (1967) reported incidence of respiratory diseases in victims of Mn poisoning.

The occurrence of zooplankton species in Cross River were probably affected by physicochemical qualities such as transparency, river-size, flow velocity and temperature. These parameters correlated significantly with all the zooplankton species. Similar trends, highlighted by other authors (Whitefield, 1990) support these finding. However, Schoener (1988) suggested that it was not only the river size that influenced the trend but more likely, the hydrological consequences (increased nutrient inputs and turbidity) of the habitat size. The author explained that increased habitat heterogeneity as a result of increased size provides greater variety of resources for species, possibly reducing competition through resource partitioning. Our study showed that habitat size and heterogeneity increased with increasing distance of sampling sites downstream but flow variability decreased downriver localities. The seasonal variation in the occurrence of zooplankton could largely be due to the Rotifera which normally constitute major diet items of larger zooplanktons. The large 
percentage of the population and the increase in its occurrence in the warmer dry season probably is associated with temperature and precipitation. With the beginning of the rainy season, nutrients are carried to the river allowing the growth of phytoplankton and this is associated with high temperature which increases zooplankton breeding and consequently a high production occurred during the dry season. In the dry season the zooplankton population appeared to have great stability and in the rainy season the population is suspected to lack stability. This may depend on the residence time of water and on the abrupt water change which occur frequently during the rainy season (Schoener, 1988).

The study has shown that the hydrology of Cross River wetlands is highly influenced by rainfall which in turn influences the water level, flow velocity, water width Secchi disc transparency, dissolved oxygen level, $\mathrm{pH}$ values and surface water temperature. Due to the changes in physical habitat characteristics of Cross River (water depth, current velocity and substrate) the river could be suspected to provide highly unstable aquatic habitat and could subsequently affect the stability of zooplankton and other aquatic organisms.

\section{ACKNOWLEDGEMENTS}

The authors wish to thank Dr. E. Ayuk, The Dean of the Faculty of Agriculture and Forestry, Cross River University of Technology, Nigeria, for his assistance with major criticism and correction of manuscript.

\section{REFERENCES}

Adebisi A.A., 1981. The physico-chemical hydrology of tropical seasonal river upper Ogun River. Hydrobiologia, 79, 157-165.

Adenji H.A. and Ovie S.I., 1981. Study of the abundance and distribution of zooplankton in Asa Lake. Journal of Environ. Issues, 1, 19-2.

Adenji H.A. and Ovie S.I., 1982. Study and appraisal for the water quality of the Asa Lake and Niger Rivers. Journal of Environ. Issues, 2, 6-10.

Akpan E.R. and Offem J.O., 1993. Seasonal variation in water quality of the Cross River State Nigeria. Hydrobiologia, 26, 95-103.

Alabaster J.S., 1982. Report of the EIFAC. Workshop on fish farm effluents, Technical Paper 41, FAO, Rome.

Antia E.S. and Holzlohner S., 1996. Bibliography of a decade 1975-1985 of coastal studies of the Cross River estuary and environs by the Institute of Oceanography, University of Calabar, Nigeria. J. Coastal Res., 1, 40-42.

APHA, 1987. American Public Health Association: Standard methods for the examination of water and waste water, Washington D.C., 1076 p.

Asuquo F.E., Ntekim E.E., Eja A.O., Ekwu A.O., Ogri O.O. and Bassey E.S., 1999. Post impact assessment of Cross River coastal areas affected by Mobil (Idoho) oil spillage. Report submitted to Cross River Govt., 23 p.

Ayodele I.A. and Ajani E.K., 1999. Essentials of fish farming (aquaculture). Odufuwa publishers, Ibadan.

Azionu B.C., 1983. Spatial and diet variations in some hydrological features of the Shehu Reservoir, Plateau State. J. Aquat. Sci., 10, 14-20.

Bayley P.B., 1981. Caracteristicas de inundacion de los riosy areas de Captacion en la Amazonia peruana. Inf. No. 81, Institute del mar del Peru, 245 p.

Boyd C.E., 1979. Water quality in warm water fish ponds. Auburn University publishers, Auburn.

Boyd C.E., 1981. Water quality in warm water fish ponds. Auburn University publishers, Auburn.

Egborge A.B.M., 1977. The Hydrology and Plankton of Asejire Lake. University of Ibadan publishers, Ibadan.

Egborge A.B., 1994. Biodiversity and chemistry of Warri River. Ben Miller, Warri, 23-45.

Enrique V., 1992. Temperature and dissolved oxygen in Lake of the Lower River Floodplain (Venezuela). Hydrobiologia, 25, 23-33.

European Economic Community (EEC), 1976. EC Standards for surface waters used for portable Abstractions. EEC, Brussels, 23-45. 
European Economic Community (EEC), 1980. EC Drinking Water Standards. Directive 80/778/EEC EEC, Brussels.

Ezra A.G. and Nwankwo D.I., 2001. Composition of phytoplankton algae in Gubi reservoir, Bauchi, Nigeria. J. Aquat. Sci., 16, 115-118.

FEPA: Federal Environmental Protection Agency, 1989. Our National environmental goals. Special Publication No. 3, Federal Environmental Protection Agency, Lagos.

Framan M.A.H., 1981. Standard method for the analysis of water and waste water. APHA, Washington, 45-56.

Golterman H.I., 1969. Methods for chemical analysis of fresh water. International Biological Program Handbook \& Blackwell Scientific publications, Oxford, $172 \mathrm{p}$.

Grossman G.D. and Freeman M.C., 1987. Micro habitat use in stream fish assemblage. J. Zool., 212, 151-176.

Hassan A.T., 1974. Studies on ecological behaviour and life history of Libelluline dragon fly. University of Ibadan publishers, Ibadan.

Herschy R.W., 1999. Hydrometry principles and practice, John Willey and Sons, Chichester, $12 \mathrm{p}$.

Hodgson E. and Levi P.E., 1987. A text book of modern toxicology, Elsevier, London, 90 p.

Imevbore A.M.A., 1967. Hydrobiology and plankton of Eleyele Reservoir, Ibadan, Nigeria. Hydrobiologia, 30, 154-175.

Izonfuo L.W.A. and Bariweni A.D., 2001. The effects of urban runoff water and human activities of some physico-chemical parameters of the Epie Creek in the Niger Delta. J. Appl. Sci. Environ. Managt., $5,47-56$.

Jamu D.M. and Ayinla O.A., 2003. Potential for the development of Aquaculture in Africa. NAGA, 693, 9-13.

Khan M.A. and Ejike A., 1984. Limnology and plankton periodicity of Jos Plateau water reservoir, Nigeria. Hydrobiologia, 114, 189-199.

King R.P., 1988. New observations on the trophic ecology of Liza grandisquamis (Valencienne 1836) (Pisces: Mugillidae) in the Bonny River, Niger Delta, Nigeria. Cybium, 12, 23-36.

Macan T.T., 1974. Fresh water ecology, Second edition, Longmans, London, 343 p.

Mason C.F., 1992. Biology of fresh water pollution, Wiley and Sons, New York, 351 p.

Mellanby H., 1963. Animal life in fresh water, Cox and Wyman, London, 23-34.

Mena I., Meurin O., Feunzobda S. and Cotzias G.C., 1967. Chronic Manganese poisoning. Clinical picture and Manganese turnover. Neurology, 17, 128-134.

Muller-Eberhard U., Miescher P.A. and Jaffe E.R., 1977. Iron Excess. Aberrations of Iron and Porphyrin Metabolism, Grun and Stratton, New York, 34-36.

Needham J.G. and Needham R.P., 1972. A guide to the study of fresh water biology, Holden-day, California, 23-56.

Ochang S.N., Ayotunde E.O. and Okey I.B., 2005. Some aspects of the physico-chemical and biological properties of Cross River, an inland water body in South-Eastern Nigeria. Glob. J. Agric. Sci., 4, 139-148.

Offem B.O. and Ayotunde E.O., 2008. Toxicity of Lead to Freshwater Invertebrates (Waterfleas; Daphnia magna and Cyclop sp.) in Fish Ponds in a Tropical Floodplain. Water Air Soil Pollut., 192, 39-46.

O'Flaherty E.J., 1995. Chromium toxicokinetics. In: Goyer R.A. and Clerian M.G. (eds.), Toxicology of metals, Biochemical Aspects., 32, 315-328.

Olajire A.A., Ayodele E.T., Onyedirdan G.O. and Oluyemi E.A., 2003. Levels and speciations of heavy metals in soils of Industrial Southern Nigeria. Environ. Monitor. Assess., 85, 135-144.

Ovie S.I. and Adeniji F.S., 1993. Mass production of zooplankton in outdoor concrete tanks for fish culture, New Bussa publishers, 129-135.

Pearson D., 1976. The chemical analysis of foods, Churchill-Livingstone, Edinburg, 34-38.

Rippey I. and Rippey B., 1986. Chemical limnology of two artificial lakes. Hydrobiologia, 139, 201-231.

Schoener T.W., 1988. Ecological interactions. In: Myer A.A. and Giller P.S. (eds.), Analytical biogeography, Chapman and Hall, London, 255-299.

Silva E.I.L. and Davies R.W., 1987. The seasonality of moonsoonal primary productivity in Sri Lanka. Hydrobiologia, 150, 165-1975.

Smith C.L. and Powell C.R., 1971. The Summer Fish Communities of Brier Creek, Marshall Country, Oklahoma. Am. Mus. Novit., 2459, 1-30.

Somers K.M. and Harvey H.H., 1984. Alteration of Lake fish communities in response to acid precipitation and heavy-metal loading near Wawa, Ontario, Canada. J. Aquat. Sci., 41, 20-29. 
Swingle H.S., 1969. Relationship and dynamics of balanced and unbalanced fish population. Alabama polytechnic Institute of Agriculture and Experimental Station, 12-45.

Ugwumba O.A. and Ugwumba A.A., 1993. A study of the physico-chemical hydrology and plankton of Awba Lake, Ibadan, Nigeria, Fisheries Acadbiz publishers, Ibadan, 20-30.

United Nations Commision on Sustainable Development (UNCSD), 2000. Comprehensive assessment of the Freshwater resources of the World, UN, New York.

Viner A.B., 1970. Hydrobiology of the Volta lake, Ghana I: Stratification and circulation of water. Hydrobiologia, 35, 209-229.

Walshe C.T., Sandstead H.H. and Prasad A.S., 1995. Zinc: Health effects and research priorities for the environment. Health perspects., 102, 5-46.

Ward H.B. and Whipple G.C., 1959. Fresh water biology, John Wiley and Sons, New York, 34-78.

Welcomme R.L., 1985. River fisheries FAO Fish, Tech. Paper, 262-330.

Whitefield A.K., 1990. Distribution of fishes in the Mblanga estuaries in relation to food resources. S. Afr. J. Zool., 15, 159-165.

World Health Organization, 1984. WHO Guidelines for Drinking Water Quality, WHO, Geneva, 34 p.

World Health Organization, 1998. Guidelines for Drinking water. World Health Organization Health Criteria and other supporting information, WHO, Geneva, $67 \mathrm{p}$. 